\title{
Matrine induces cell cycle arrest and apoptosis with recovery of the expression of $m i R-126$ in the A549 non-small cell lung cancer cell line
}

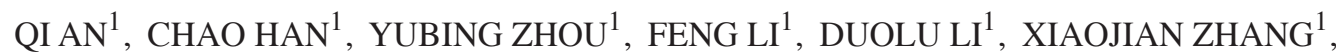 \\ ZUJIANG $\mathrm{YU}^{2}$, ZHENFENG DUAN ${ }^{3}$ and QUANCHENG KAN ${ }^{1}$
}

\begin{abstract}
Departments of ${ }^{1}$ Clinical Pharmacology and ${ }^{2}$ Infectious Diseases, The First Affiliated Hospital of Zhengzhou University, Zhengzhou, Henan 450052, P.R. China; ${ }^{3}$ Sarcoma Biology Laboratory, Center for Sarcoma and Connective Tissue Oncology, Massachusetts General Hospital, Boston, MA 02114, USA
\end{abstract}

Received July 12, 2015; Accepted August 2, 2016

DOI: $10.3892 / \mathrm{mmr} .2016 .5753$

\begin{abstract}
Non-small cell lung cancer (NSCLC) is the leading cause of cancer-associated mortality in the United States. Chemotherapy prolongs survival rates among patients with advanced disease, however, this is at the cost of clinically significant adverse effects. Matrine is an active component of traditional Chinese medicine and is a promising alternative drug for the treatment of NSCLC. In the present study, the therapeutic effects and the underlying molecular mechanisms of matrine on the A549 NSCLC cell line were investigated. A high concentration of matrine $(1.0 \mathrm{mg} / \mathrm{ml})$ significantly $(\mathrm{P}<0.05)$ inhibited cell proliferation, by $52.68 \pm 3.32 \%$, under which cell shrinkage and disruption were observed. Flow cytometric analysis showed that the proportion of $\mathrm{G} 1 / \mathrm{G} 0$ cells was significantly increased, whereas the proportions of $\mathrm{S}$ and $\mathrm{G} 2 / \mathrm{M}$ cells were significantly decreased $(\mathrm{P}<0.05)$ following treatment with matrine for $48 \mathrm{~h}$. These results indicated that cell arrest was induced by matrine. Upregulation of the expression of microRNA ( $m i R)-126$, followed by downregulation of the expression of its target gene, vascular endothelial growth factor, were detected following treatment with a low concentration of matrine $(0.2 \mathrm{mg} / \mathrm{ml})$ using reverse transcription-quantitative polymerase chain reaction analysis, immunohistochemistry and western blot analysis. In conclusion, matrine induced cell cycle arrest and apoptosis, and recovered the expression of $m i R-126$ in the A549 NSCLC cell line.
\end{abstract}

Correspondence to: Dr Quancheng Kan, Department of Clinical Pharmacology, The First Affiliated Hospital of Zhengzhou University, 1 Jianshe East Road, Zhengzhou, Henan 450052, P.R. China

E-mail:kan-qc@163.com

Key words: matrine, traditional Chinese medicine, miR-126, non-small-cell lung cancer, vascular endothelial growth factor

\section{Introduction}

Lung cancer is one of the leading causes of cancer-associated mortality worldwide, with 1,000,000 new cases annually, in terms of incidence and mortality rates (1). It accounted for $13 \%(1,600,000$ cases $)$ of the total cases of cancer and $18 \%(1,800,000$ cases $)$ of cancer-associated mortality in 2008 (2). Tobacco use is considered to be the primary cause of lung cancer, accounting for $80-90 \%$ of cases $(3,4)$, among which cigarette smoking totals $\sim 95 \%$ of tobacco use (5). Non-small-cell lung cancer (NSCLC) accounts for $\sim 80 \%$ of all cases of lung cancer (6). The management of patients with NSCLC is based on systemic chemotherapy. However, patient survival rates remains low. Additionally, although chemotherapy can prolong survival rates among patients with advanced disease, clinically significant adverse effects reduce its efficacy as excessive toxicity is often reported (7).

Traditional chemotherapy remains an important therapeutic strategy for human cancer. However, the majority of chemotherapeutic drugs for the treatment of NSCLC are cytotoxic agents with a high risk of side effects, including adriamycin, cisplatin, 5-fluorouracil and doxorubicin $(8,9)$. Furthermore, chemoresistance can develop in patients with NSCLC, which presents a major obstacle to the long-term efficacy of chemotherapeutic treatments $(10,11)$. Therefore, alternative treatments require development to improve the efficiency of NSCLC therapy.

Traditional Chinese medicine (TCM) is valued for its 5,000-year-old history and retains an important position in primary healthcare in China. TCM can complement Western medicine using modern techniques, thus, TCMs have increased in interest in Western countries. Sophora flavescens Ait is a TCM widely used for several diseases, including viral hepatitis, cardiac arrhythmia, lung cancer and skin inflammation, in China (12). The active components of Sophora flavescens are various alkaloids, among which matrine has been characterized as the major bioactive component (13).

As an alkaloid, matrine has favorable medical effects. Its antiviral activity is promising in the treatment of chronic hepatitis B (14). It has been reported that intramuscular injection 
of matrine improves the clinical symptoms of patients with chronic hepatitis $\mathrm{B}$, recovers liver function and alters serum conversion from positive to negative hepatitis B virus DNA (15). It has also been shown that matrine exerts antifibrotic activity, which inhibits the activities of platelet-derived growth factor and transforming growth factor- $\beta$ in hepatic stellate cells (16). Previous studies have shown that matrine is effective at inhibiting cell growth and inducing differentiation in human leukemia K562 cells $(13,17,18)$. Matrine is also a differentiation inducer in SMMC-7721 cells (19). In human multiple myeloma cells and MKN45 gastric cancer cells, matrine can induce tumor cell apoptosis by interrupting cell-cell adhesion and inhibiting cancer metastasis $(20,21)$, and matrine can also prevent tumor invasion (22). Consequently, matrine may be a promising alternative anticancer drug for the treatment of NSCLC. In China, matrine has been used for the treatment of NSCLC in mice (23), however, the antitumor therapeutic efficacy and the underlying molecular mechanisms of matrine, with respect to the physiological and pharmacological effects on human NSCLC, remain to be fully elucidated.

In the present study, the therapeutic effects and the underlying molecular mechanisms of matrine on the A549 human NSCLC cell line were investigated. This included investigation of its inhibitory effect on cell proliferation, alterations of cell morphology and induction of cell apoptosis, and the expression of microRNA ( $m i R)-126$ and its target gene, vascular endothelial growth factor (VEGF), as $m i R-126$ is known to be downregulated in NSCLC cell lines, including A549 (24). Matrine may serve as a promising TCM for NSCLC therapy.

\section{Materials and methods}

Cell line and matrine treatment. The A549 human NSCLC cell line was purchased from the Cancer Research Institute of China Medical University (Shenyang, China). The cells were cultured in Dulbecco's modified Eagle's medium (DMEM; Gibco; Thermo Fisher Scientific, Inc., Waltham, MA, USA) supplemented with $10 \%(\mathrm{~m} / \mathrm{v})$ fetal bovine serum (Gibco; Thermo Fisher Scientific, Inc.), $100 \mathrm{U} / \mathrm{ml}$ penicillin and $100 \mu \mathrm{g} / \mathrm{ml}$ streptomycin on culture plates at $37^{\circ} \mathrm{C}$ in a $5 \% \mathrm{CO}_{2}$ atmosphere with stable humidity. The density of cells was $1 \times 10^{5}$ cells $/ \mathrm{ml}$ prior to culture. Matrine was obtained from Xian Botany Garden (Shanxi, China), and its purity was $>99 \%$ as assessed by high performance liquid chromatography. The matrine stock solution was prepared in $\mathrm{ddH}_{2} \mathrm{O}$ at $10 \mathrm{mg} / \mathrm{ml}$. Log-phase growing cells were seeded at a density of $1 \times 10^{5}$ cells $/ \mathrm{ml}$ and exposed to matrine at concentrations, 0 (negative control), $0.2,0.5,0.8$ and $1.0 \mathrm{mg} / \mathrm{ml}$ for $48 \mathrm{~h}$ at $37^{\circ} \mathrm{C}$.

MTT assay. The effects of matrine on cell viability were assessed busing an MTT assay, as described previously (25). Specifically, the cells were plated at a density of 3,000 cells per well into 96-well plates. At the end of treatment, the supernatant was removed, following which $20 \mu \mathrm{l}$ of the tetrazolium compound, MTT, and $270 \mathrm{ml}$ fresh Iscove's modified Dulbecco's medium (NewTopBio Co., Shenzhen, China) were added. Following incubation for $4 \mathrm{~h}$ at $37^{\circ} \mathrm{C}, 120 \mu \mathrm{l}$ of DMSO was added to each well to dissolve the tetrazolium crystals. Finally, the absorbance at a wavelength of $570 \mathrm{~nm}$ was recorded using a multi-well plate reader (Tecan Schweiz AG, Maennedorf, Switzerland). Each experiment was performed four times. The results are expressed as the percentage growth inhibition with respect to the untreated cells.

Microscopic examination. The cells were digested by trypsin-EDTA, washed and resuspended in serum-free medium, counted and then fixed overnight in $75 \%$ ethanol at $4^{\circ} \mathrm{C}$. The cells were washed and resuspended in phosphate-buffered saline (PBS; $\mathrm{pH} 7.4)$. The digested cell culture $\left(3 \times 10^{5}\right.$ cells $\left./ \mathrm{ml}\right)$ was added to a 24 -well plate $(0.9 \mathrm{ml}$ in each well) and incubated for $12 \mathrm{~h}$ at $37^{\circ} \mathrm{C}$. Subsequently, $0.1 \mathrm{ml} /$ well of matrine at a low $(0.2 \mathrm{mg} / \mathrm{ml})$ or high $(1.0 \mathrm{mg} / \mathrm{ml})$ concentration was added. The cells were incubated for $48 \mathrm{~h}$ at $37^{\circ} \mathrm{C}$ prior to observation. The cells were examined using an Olympus IX70 inverted microscope (Olympus Corporation, Tokyo, Japan), a DVC1310 digital video camera (DVC Co., Austin, TX, USA) and a QED camera (Media Cybernetics, Inc., Rockville, MD, USA) with Standalone 145 software (Media Cybernetics, Inc.).

Flow cytometry (FCM). A549 cells in the log phase were collected at a final concentration of $2 \times 10^{5}$ cells $/ \mathrm{ml}$, and were incubated in a 6 -well plate for $12 \mathrm{~h}$ at $37^{\circ} \mathrm{C}(2.7 \mathrm{ml}$ in each well $)$. Subsequently, matrine at a low $(0.2 \mathrm{mg} / \mathrm{ml})$ or high $(1.0 \mathrm{mg} / \mathrm{ml})$ concentration $(0.3 \mathrm{ml}$ per well) was added to induce the cells for $48 \mathrm{~h}$. Simultaneously, $0.3 \mathrm{ml}$ of cell culture, as a negative control, was cultured for $48 \mathrm{~h}$ at $37^{\circ} \mathrm{C}$, collected, washed with PBS, and fixed with $70 \%$ ethanol, in sequence. The cells were centrifuged at $5,300 \mathrm{x} \mathrm{g}$ for $5 \mathrm{~min}$ at $4{ }^{\circ} \mathrm{C}$ to eliminate ethanol, washed with PBS and stained with propidium iodide in the dark for 30 min prior to analysis using FCM. Finally, a BD FACSCalibur flow cytometer (BD Biosciences, Franklin Lakes, NJ, USA) was used to detect cell cycle. The cells were sampled using CellQuest 3.0 sampling software (BD Biosciences). The proportion of cells in the different phases were quantified using ModFitLT 3.0 (26). Each experiment was performed four times.

Measurement of apoptosis. The cells $\left(1 \times 10^{6}\right)$ were treated with $0,0.2,0.5,0.8$ and $1.0 \mathrm{mg} / \mathrm{ml}$ matrine for $48 \mathrm{~h}$ at $37^{\circ} \mathrm{C}$, and then collected by centrifugation at $5,300 \mathrm{x}$ for $5 \mathrm{~min}$ at $4^{\circ} \mathrm{C}$. The pellets were lysed in DNA lysis buffer, containing $10 \mathrm{mM}$ Tris (pH 7.5), 400 mM EDTA and 1\% Triton X-100, and then centrifuged at $5,300 \mathrm{x} \mathrm{g}$ for $5 \mathrm{~min}$ at $4^{\circ} \mathrm{C}$. The supernatant obtained was incubated overnight at $37^{\circ} \mathrm{C}$ with proteinase $\mathrm{K}(0.1 \mathrm{mg} / \mathrm{ml})$ and then with RNase $(0.2 \mathrm{mg} / \mathrm{ml})$ for $2 \mathrm{~h}$ at $37^{\circ} \mathrm{C}$. Following extraction with phenol chloroform (1:1), DNA was separated on $2 \%$ agarose gel and visualized under UV following staining with ethidium bromide. The quantitative assessment of apoptotic cells was assessed using the terminal deoxynucleotidyl transferase-mediated deoxyuridine triphosphate nick-end labeling (TUNEL) method, which was performed to examine DNA-strand breaks during apoptosis using a BD ApoAlert DNA Fragmentation Assay kit (BD Biosciences).

Immunohistochemical (IHC) staining. IHC staining was performed using the specific affinity-purified polyclonal anti-VEGF antibody. As a negative control, nonimmune serum was used instead of the primary antibody. Briefly, the cells were washed in PBS followed by preincubation with 
Table I. Changes in cell cycle induced by matrine.

\begin{tabular}{lrrrr}
\hline Group & Cell debris $(\%)$ & Apoptosis $(\%)$ & Diploid $(\%)$ & Aneuploid (\%) \\
\hline Control & $1.76 \pm 0.1891$ & $0.0309 \pm 0.0165$ & $93.9335 \pm 3.977$ & $6.0665 \pm 4.3721$ \\
Matrine & & & & \\
$0.2(\mathrm{mg} / \mathrm{ml})$ & $18.8967 \pm 3.9119$ & $0.0400 \pm 0.0693$ & $98.7367 \pm 1.4318$ & $1.2401 \pm 1.4673$ \\
$1.0(\mathrm{mg} / \mathrm{ml})$ & $47.0597 \pm 4.9622$ & $0.07097 \pm 0.0689$ & $98.9799 \pm 0.1605$ & $1.0201 \pm 0.1394$ \\
\hline
\end{tabular}

Data are presented as the mean \pm standard deviation.

$1.5 \%$ normal goat serum in phosphate buffer within a moist chamber for $4 \mathrm{~h}$ at room temperature. These cells were then incubated overnight at $4^{\circ} \mathrm{C}$ with rabbit polyclonal anti-VEGF antibody (1:100; Sigma-Aldrich; Merck Millipore, Darmstadt, Germany; cat. no. HPA027342) at a final concentration of $2 \mu \mathrm{g} / \mathrm{ml}$. Following being washed six times with PBS containing $0.02 \%$ Triton X-100 for $15 \mathrm{~min}$, the slides were processed for immunostaining using the avidin-biotinylated peroxidase complex method (Vector Laboratories, Inc., Burlingame, CA, USA), according to the manufacturer's protocol. The cells were briefly counterstained with Mayer's hematoxylin prior to mounting. The cultured cells were grown on sterile coverslips in tissue culture dishes overnight, fixed with $45 \%$ acetone $/ 10 \%$ formaldehyde in $0.1 \mathrm{M}$ phosphate buffer for $5 \mathrm{~min}$, and then processed for the IHC assay as described previously (27).

Reverse transcription-quantitative polymerase chain reaction (RT-qPCR analysis. The expression of mature miR-126 in the A549 cells was assayed using a Taqman MicroRNA assay (Applied Biosystems; Thermo Fisher Scientific, Inc.). Each sample was analyzed in triplicate. Total RNA was extracted using TRIzol (Thermo Fisher Scientific, Inc.) according to the manufacturer's protocols. The RT reaction was performed on a $10 \mathrm{ng}$ sample of total RNA using looped primers. qPCR analysis was performed using the standard Taqman MicroRNA assay protocol on a 7500 Real-Time PCR System (Applied Biosystems; Thermo Fisher Scientific, Inc.). The $20 \mu \mathrm{l}$ PCR sample comprised $1.33 \mu \mathrm{l}$ of the RT product, 1X Taqman Universal PCR Master Mix without AmpErase UNG (cat. no. 4324018; Applied Biosystems; Thermo Fisher Scientific, Inc.), $0.2 \mu \mathrm{mol} / 1$ Taqman probe, $1.5 \mu \mathrm{mol} / 1$ forward primer and $0.7 \mu \mathrm{mol} / 1$ reverse primer. The reactions were performed in a 96 -well plate at $95^{\circ} \mathrm{C}$ for $10 \mathrm{~min}$, followed by 40 cycles of $95^{\circ} \mathrm{C}$ for $15 \mathrm{sec}$ and $60^{\circ} \mathrm{C}$ for $1 \mathrm{~min}$. The primers used were as follows: Forward, 5'-TACCTCCACCATGCC AAGTG-3', and reverse, 5'-ATGATTCTGCCCTCCTCC TTC-3'. The $\Delta \Delta \mathrm{Cq}$ method for relative quantitation of gene expression levels was used to determine the miRNA expression levels. The $\Delta \Delta \mathrm{Cq}$ was calculated by subtracting the $\mathrm{Cq}$ value of U6 RNA from the Cq value of the miRNA of interest. The $\Delta \Delta \mathrm{Cq}$ was calculated by subtracting the $\Delta \mathrm{Cq}$ value of the reference sample (untreated A549 cells) from the $\Delta \mathrm{Cq}$ value of each sample. The fold change was calculated using the $2^{-\Delta \Delta C q}$ equation. A pool of three reference samples was used for standard curve calculation and as a reference sample for the $\Delta \Delta \mathrm{Cq}$. The Taqman MicroRNA Assay for U6 RNA was used to normalize the relative abundance of miRNA.
Western blot analysis. The cell lysates were prepared in RIPA buffer containing $50 \mathrm{mmol} / \mathrm{l}$ Tris- $\mathrm{HCl}$ buffer ( $\mathrm{pH} 7.4$ ), $150 \mathrm{mmol} / 1 \mathrm{NaCl}, 1 \%$ Triton $\mathrm{X}-100,1 \%$ sodium deoxycholate and $0.1 \%$ sodium dodecyl sulfate, supplemented with $1 \mathrm{X}$ Halt protease inhibitor cocktail and 1X Halt phosphatase inhibitor cocktail (Pierce; Thermo Fisher Scientific, Inc.). A Bio-Rad protein assay (Bio-Rad Laboratories, Inc.) was used to determine protein concentrations. The proteins ( $100 \mathrm{ng})$ were separated on 10-12\% sodium dodecyl sulfate-polyacrylamide gels by electrophoresis and transferred onto PVDF membranes (Whatman, Boston, MA, USA). The membranes were first hybridized with mouse monoclonal anti-VEGF antibody (1:800; Sigma-Aldrich; Merck Millipore; cat. no. SAB1402390) overnight at $4^{\circ} \mathrm{C}$ and then with horseradish peroxidase (HRP)-conjugated secondary antibodies $(1: 3,000$; Cell Signaling Technology, Inc., Danvers, MA, USA; cat. no. 7072 ) at $25^{\circ} \mathrm{C}$ for $1 \mathrm{~h}$. The protein bands were visualized using a commercial Immobilon Western Chemiluminescent HRP Substrate detection reagent (EMD Millipore, Billerica, MA, USA). The chemiluminescence of proteins transferred onto PVDF membranes was detected with ECL Plus (GE Healthcare, Piscataway, NJ, USA). Relative protein expression values were quantitatively determined via densitometry with ImageJ software (version 2.1.4.7; imagej.nih.gov/).

Statistical analysis. All data were analyzed with the SPSS 16.0 statistical software package (SPSS, Inc., Chicago, IL, USA). The results are expressed as the mean \pm standard deviation. The statistical significance of the results were determined using the parametric unpaired Student's $t$-test. $\mathrm{P}<0.05$ was considered to indicate a statistically significant difference.

\section{Results}

Matrine induces growth inhibition of A549 cells. To examine the growth-modulatory effects of matrine on A549 cells, a wide concentration range of matrine $(0.2,0.5,0.8$ and $1.0 \mathrm{mg} / \mathrm{ml})$ was used. Following treatment with matrine for $48 \mathrm{~h}$, significant $(\mathrm{P}<0.05)$ inhibition of cell growth was observed at high concentrations of 0.8 and $1.0 \mathrm{mg} / \mathrm{ml}$, compared with the control groups, with average rates of growth inhibition of $45.28 \pm 4.18$ and $52.68 \pm 3.32 \%$, respectively (Fig. 1A). However, low concentrations of matrine $(0.2$ and $0.5 \mathrm{mg} / \mathrm{ml})$ had no significant effect on cell growth, compared with the control groups. These results indicated that the growth inhibitory effect of matrine on A549 cells was concentration-dependent (Fig. 1A). 
A
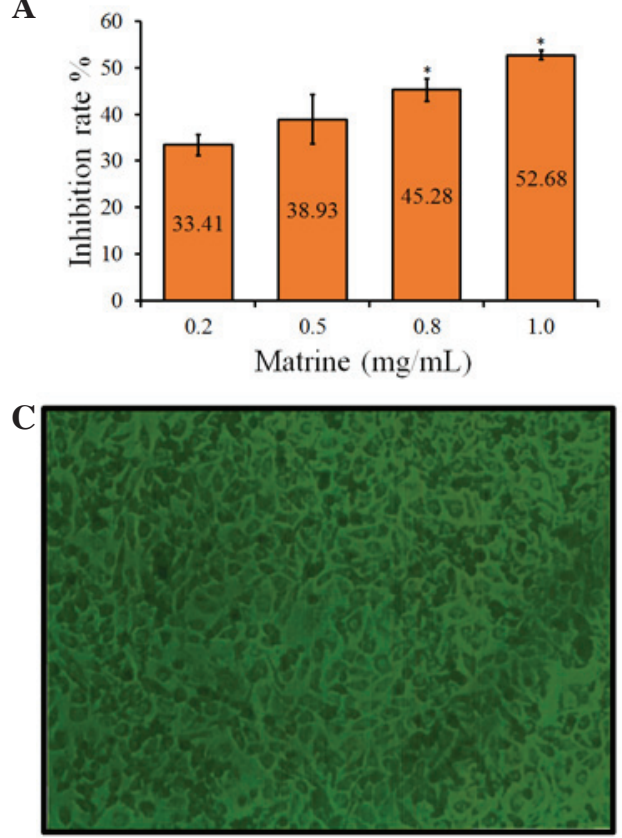

B

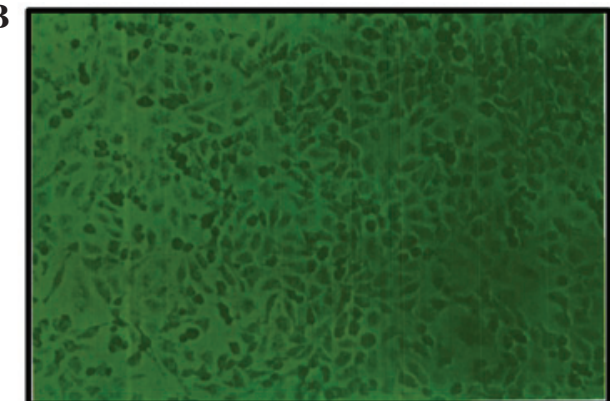

$\mathbf{D}$

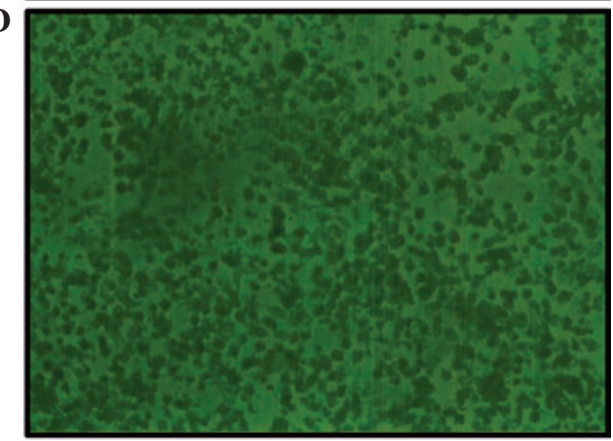

Figure 1. Growth inhibitory effect and cellular morphological changes induced by matrine (0.2, 0.5, 0.8 and $1.0 \mathrm{mg} / \mathrm{ml})$ on A549 cells. (A) Growth inhibitory data are expressed as the mean \pm standard deviation $(n=4)$. ${ }^{*} \mathrm{P}<0.05$, compared with the control group. Results are expressed as the percentage growth inhibition with respect to the untreated cells. Cellular morphological changes following treatment with matrine at different concentrations for $48 \mathrm{~h}$ were observed using fluorescence-imaging micro-spectrophotometer (magnification, x100). Compared with the (B) control group, no morphological changes were observed in the cells treated with a (C) low concentration of matrine $(0.2 \mathrm{mg} / \mathrm{ml})$. Morphological changes, including cell shrinking, disruption and destruction, were observed in the cells treated with a (D) high concentration of matrine $(1.0 \mathrm{mg} / \mathrm{ml})$, compared with the control group.
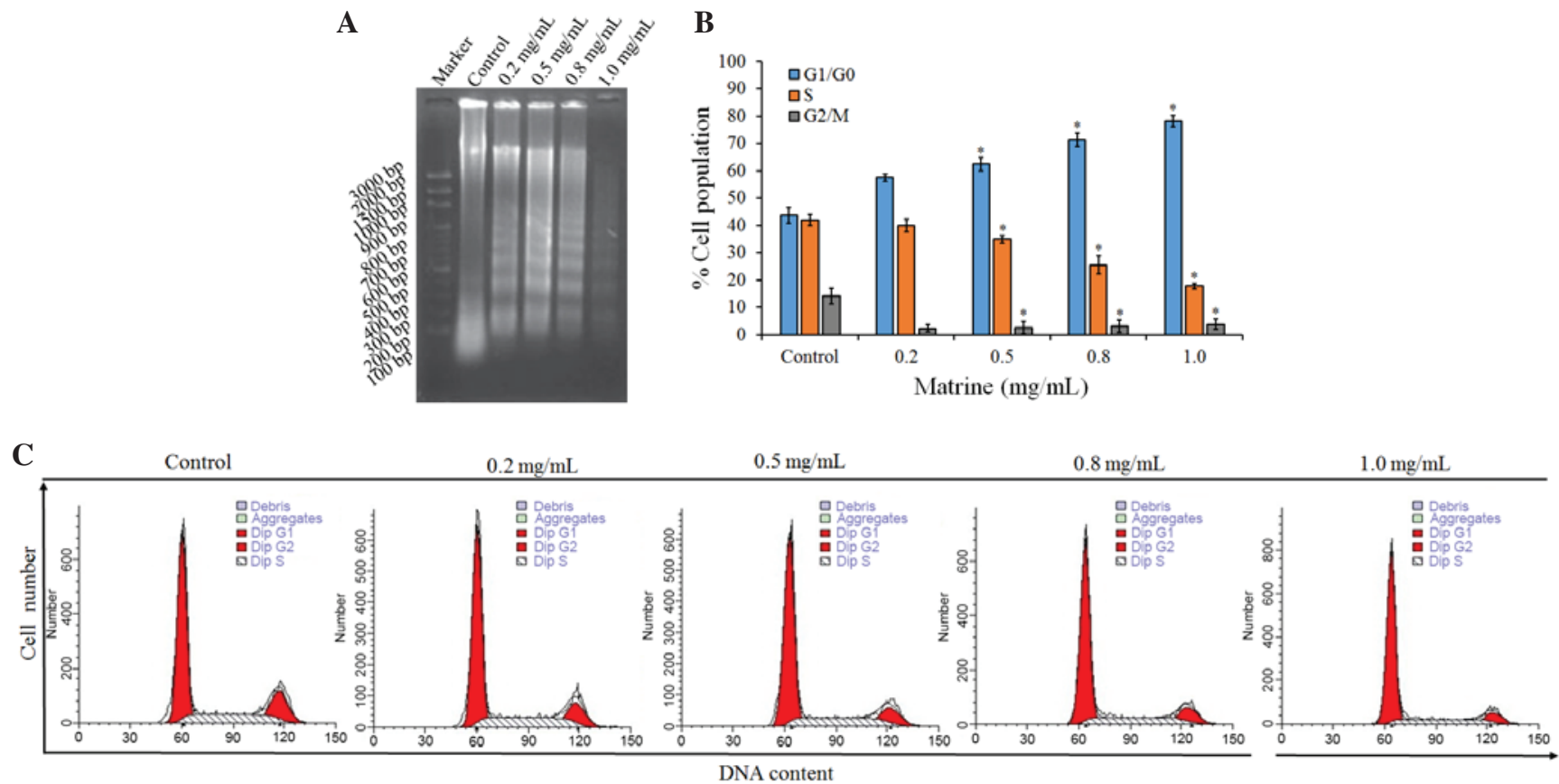

Figure 2. Effects of matrine on cell-cycle arrest and apoptosis in A549 cells. (A) DNA fragmentation of A549 induced by matrine, as determined using an electrophoresis assay $48 \mathrm{~h}$ following treatment with various concentrations of matrine. (B) Quantitative evaluations of terminal deoxynucleotidyl transferase-mediated deoxyuridine triphosphate nick end labeling assay using flow cytometry. (C) Distribution of the cell cycle in the matrine-treated cells. Each value is presented as the mean \pm standard deviation of three determinations. ${ }^{*} \mathrm{P}<0.05$ control, vs. matrine-treated cells.

Cellular morphological changes. Following treatment with matrine for $48 \mathrm{~h}$, the morphology of the cells was observed using a fluorescence-imaging micro-spectrophotometer. Compared with the control group (Fig. 1B), treatment with matrine at a low concentration $(0.2 \mathrm{mg} / \mathrm{ml}$ had no significant effect on cellular morphology (Fig. 1C), whereas marked morphological changes, including cell shrinkage, disruption and destruction were observed in the cells treated with a high concentration of matrine $(1.0 \mathrm{mg} / \mathrm{ml})$, compared with the control group (Fig. 1D). Therefore, a high concentration of 


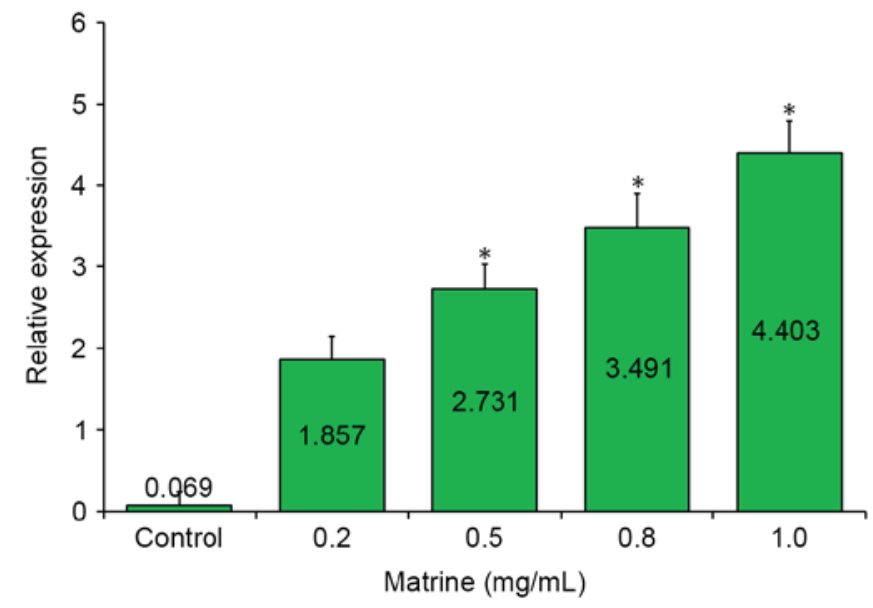

Figure 3. Relative expression of $m i R-126$ in A549 cells treated matrine Expression levels of were determined following treatment with different concentrations of matrine, standardized by the negative control (untreated cells). Data are presented as the mean \pm standard deviation. ${ }^{*} \mathrm{P}<0.05$, compared with the control. $m i R$, microRNA.

matrine led to a decrease in cell colony size, which was also indicated by the decrease in cell diopter (Fig. 1C).

Cell apoptosis is induced by matrine. To examine the mechanism responsible for the matrine-mediated inhibition of cell proliferation, cell-cycle distribution was evaluated using FCM. Compared with the control groups, treatment with matrine led to a significant $(\mathrm{P}<0.05)$ increase in the ratio of cells in the G1/G0 phase, and significant $(\mathrm{P}<0.05)$ decreases in the ratios of cells in the $S$ and $\mathrm{G} 2 / \mathrm{M}$ phases, the majority of cells remained at the G1 phase following treatment with matrine at low and high concentrations $(0.2$ and $1.0 \mathrm{mg} / \mathrm{ml}$; Table I). The proportion of diploid cells increased marginally, whereas that of aneuploid cells decreased. Cell debris increased, compared with the control group.

The effect of matrine on the induction of apoptosis in A549 cells was also examined using a DNA fragmentation assay. Agarose gel electrophoresis at $48 \mathrm{~h}$ showed that matrine treatment resulted in the formation of DNA fragments in the A549 cells (Fig. 2A). Quantitative evaluation was also performed using a TUNEL assay to detect DNA-strand breaks. Compared with the control cells at $48 \mathrm{~h}$, treatment with $1.0 \mathrm{mg} / \mathrm{ml}$ matrine induced apoptosis of $\sim 30 \%$ of the A549 cells (Fig. 2B). The results showed that treating the cells with matrine caused a significant inhibition of cell-cycle progression in the A549 cells (Fig. 2C), resulting in an increase of the percentage of cells in the G1 phase, compared with the control.

miR-126 is upregulated in matrine-treated cells. To examine the correlation between matrine treatment and the expression of $m i R-126$, the relative expression of $m i R-126$ was detected among the samples by RT-qPCR analysis. As shown in Fig. 3, a markedly upregulated expression of $m i R-126$ was observed in the matrine-treated A549 cells, compared with the control in the RT-qPCR assay. This upregulation was further enhanced by increasing the concentration of matrine, and reached its peak $(\sim 4.4$-fold $)$, when the matrine concentration was increased to $1.0 \mathrm{mg} / \mathrm{ml}$.
A

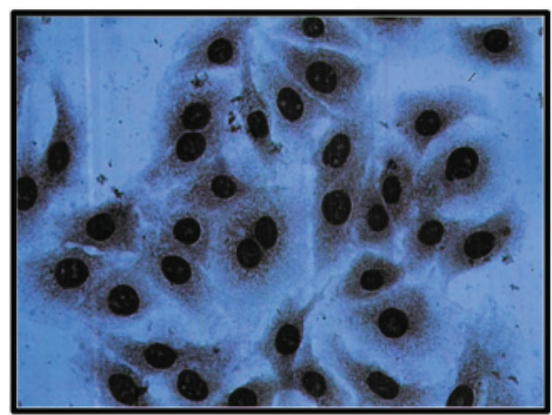

B

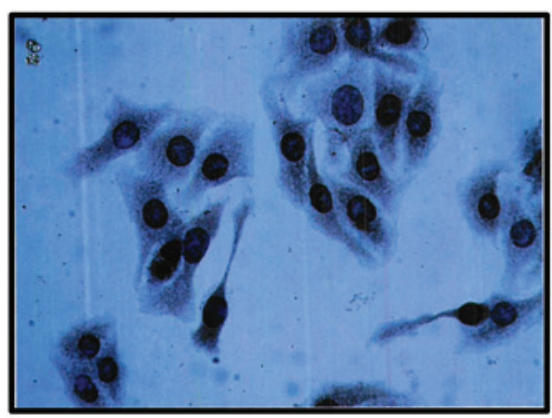

C

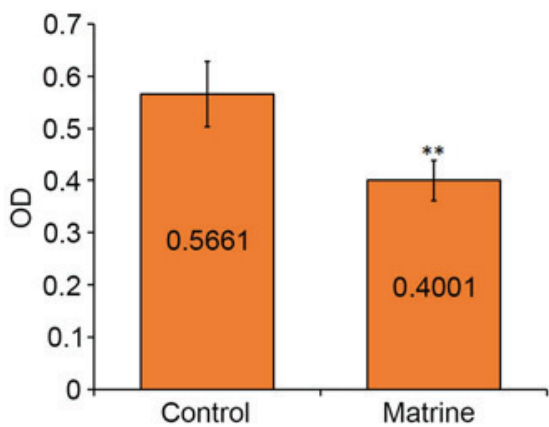

D

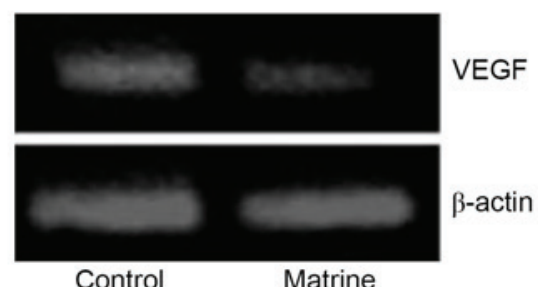

Figure 4. Gene expression of VEGF in A549 cells. Compared with the (A) control group, a (B) low concentration $(0.2 \mathrm{mg} / \mathrm{ml})$ of matrine significantly $(\mathrm{P}<0.01)$ inhibited the gene expression of $V E G F$, as indicated by immunohistochemical staining (magnification, $\mathrm{x} 400$ ). (C) Mean OD values. (D) western blot. Data are expressed as the mean \pm standard deviation. ${ }^{* *} \mathrm{P}<0.01$, compared with the control group. $V E G F$, vascular endothelial growth factor; OD, optical density.

Downregulation of the miR-126 target, VEGF, is induced by matrine treatment. IHC staining showed that almost all the cell nuclei and brown cytoplasmic particles were sepia-colored following treatment with matrine at a low concentration $(0.2 \mathrm{mg} / \mathrm{ml})$ for $48 \mathrm{~h}$ (Fig. 4A and B). The mean optical density (OD) value of each group indicated the expression level of the VEGF gene. The mean OD of the control group was $0.5661 \pm 0.0298$; whereas that of the matrine-treated group was $0.4001 \pm 0.0766$. The mean OD of the matrine-treated group was significantly $(\mathrm{P}<0.01)$ higher, compared with that of the 
control group (Fig. 4C), suggesting that the low concentration of matrine was sufficient to inhibit the gene expression of $V E G F$. These results were also confirmed using western blot analysis (Fig. 4D). The band of the control cells was brighter ( 1.5 -fold), compared with that of the matrine-treated cells (Fig. 4D).

\section{Discussion}

Although traditional chemotherapy remains the primary method of cancer therapy, cancer cells often develop drug resistance, which significantly reduces the efficiency of chemotherapeutic treatment. Furthermore, due to the poor prognosis associated with certain types of lung cancer and limited treatment options besides surgery, patients may seek alternative treatments, including TCMs, alone or in combination with standard care (28). In previous years, the potential of natural products from the medicinal plants used in TCM has been recognized by the scientific community in Western countries. Several natural products and derivatives thereof belong to the standard repertoire of cancer chemotherapeutic agents (29). Novel TCM-derived anticancer drugs include arsenic trioxide, camptothecin, cantharidin, homoharringtonine, podophyllotoxin, vinblastine and vincristine (27). There is evidence that these anticancer TCMs function as inducers of apoptosis to inhibit cell growth through genes involved in regulating cell proliferation, angiogenesis or apoptosis $(30,31)$, and immune-enhancers to improve immunological function or resistance against tumors and viruses (32).

The results of the present study suggested that matrine was important in suppressing tumor cell growth in the A549 human NSCLC cell line. Matrine decreased the survival of A549 cells in a dose-dependent manner. The present study found that a low concentration $(0.2 \mathrm{mg} / \mathrm{ml})$ of matrine was sufficient to inhibit A549 cell growth; this cell growth arrest was concentration-dependent, with an elevated inhibitory effect observed when the concentration of matrine increased (Fig. 1A). However, no significant changes in cell morphology were observed at a low concentration $(0.2 \mathrm{mg} / \mathrm{ml})$ until the concentration increased to $1.0 \mathrm{mg} / \mathrm{ml}$ (Fig. 2). In addition to cell growth arrest, A549 cell apoptosis was induced following matrine treatment for $48 \mathrm{~h}$, as indicated by changes in the cell cycle, compared with the untreated control, detected using FCM (Fig. 2). Significant $(\mathrm{P}<0.05)$ decreases in the proportion of cells in the $\mathrm{S}$ and $\mathrm{G} 2 / \mathrm{M}$ phases, followed by an increase in proportion of cells in the $\mathrm{G} 1 / \mathrm{G} 0$ phase were observed following treatment with matrine at low and high concentrations $(0.2$ and $1.0 \mathrm{mg} / \mathrm{ml}$ ), which was in agreement with the MTT assay (Table I and Fig. 1A). These results were similar to the previously reported inhibitory effect of matrine on murine $\mathrm{H} 22$ cell proliferation (12). In contrast to the concentration-dependent effect of matrine on the murine $\mathrm{H} 22$ cells, in which inhibition occurred following treatment with $0.5 \mathrm{mg} / \mathrm{ml}$ matrine for $48 \mathrm{~h}$, treatment with a low concentration of matrine $(0.2 \mathrm{mg} / \mathrm{ml})$ for $48 \mathrm{~h}$ was sufficient to induce apoptosis of the A549 NSCLC cells in the present study. These results indicated that a low concentration of matrine inhibited A549 cell proliferation by retarding cell growth to prolong the cell cycle.

The proportion of cell apoptosis in the present study was low (Table I), indicating that the inhibitory effect of matrine on the A549 cells was predominantly caused by cell cycle retardation, comprising cell growth extension and decelerated proliferation, rather than cell apoptosis. The increase of cells in the G1/G0 phase, and decrease of cells in the S and G2/M phases suggested that the inhibitory effect of matrine on A549 proliferation was predominantly attributed to cell cycle arrest at the G1 phase. However, further investigations are required to confirm these results and to investigate the underlying mechanism.

miR-126 is often downregulated in NSCLC-derived cell lines (24). Using RT-qPCR analysis, the expression of $m i R-126$ was determined in the present study. Compared with the untreated A549 control cells, a dose-dependent upregulation of $m i R-126$ was observed in the matrine-treated groups (Fig. 3) suggesting a correlation between matrine and $m i R-126$ in the A549 cells. This was supported by the downregulation of $V E G F$, a target of miR-126 (24) observed using western blot analysis (Fig. 4D). A low concentration of matrine $(0.2 \mathrm{mg} / \mathrm{ml})$ inhibited the expression of $V E G F$, which was $\sim 1.5$-fold lower, compared with that in the control group, and was inversely correlated with the expression of miR-126, by $\sim 1.857$-fold (Fig. 3 ). These results indicated that the antitumor TCM matrine induced cell cycle arrest and apoptosis, and recovery of the expression of $m i R-126$ in the A549 NSCLC cell line.

\section{References}

1. Ettinger DS, Akerley W, Borghaei H, Chang AC, Cheney RT, Chirieac LR, D'Amico TA, Demmy TL, Ganti AK, Govindan R, et al: Non-small cell lung cancer. J Natl Compr Canc Netw 10: 1236-1271, 2012.

2. Siegel R, Naishadham D and Jemal A: Cancer statistics, 2012. CA Cancer J Clin 62: 10-29, 2012.

3. Biesalski HK, Bueno de Mesquita B, Chesson A, Chytil F, Grimble R, Hermus RJ, Köhrle J, Lotan R, Norpoth K, Pastorino U and Thurnham D: European consensus statement on lung cancer: Risk factors and prevention. Lung cancer panel. CA Cancer J Clin 48: 167-176; discussion 164-166, 1998.

4. Secretan B, Straif K, Baan R, Grosse Y, El Ghissassi F, Bouvard V, Benbrahim-Tallaa L, Guha N, Freeman C, Galichet L, et al: A review of human carcinogens-Part E: Tobacco, areca nut, alcohol, coal smoke, and salted fish. Lancet Oncol 10: 1033-1034, 2009.

5. Martínez-Sánchez JM, Fernández E, Fu M, Gallus S, Martínez C, Sureda X, La Vecchia C and Clancy L: Smoking behaviour, involuntary smoking, attitudes towards smoke-free legislations, and tobacco control activities in the European Union. PLoS One 5: e13881,2010.

6. Fossella FV, DeVore R, Kerr RN, Crawford J, Natale RR, Dunphy F, Kalman L, Miller V, Lee JS, Moore M, et al; TAX Non-Small-Cell Lung Cancer Study Group: Randomized phase III trial of docetaxel versus vinorelbine or ifosfamide in patients with advanced non-small-cell lung cancer previously treated with platinum-containing chemotherapy regimens. JCO 18: 2354-2362, 2000.

7. Schiller JH, Harrington D, Belani CP, Langer C, Sandler A, Krook J, Zhu J and Johnson DH; Eastern Cooperative Oncology Group: Comparison of four chemotherapy regimens for advanced non-small-cell lung cancer. N Engl J Med 346: 92-98, 2002.

8. Avila MA, Berasain C, Sangro B and Prieto J: New therapies for hepatocellular carcinoma. Oncogene 25: 3866-3884, 2006.

9. Llovet JM and Bruix J: Systematic review of randomized trials for unresectable hepatocellular carcinoma: Chemoembolization improves survival. Hepatology 37: 429-442, 2003.

10. Hartmann TN, Burger JA, Glodek A, Fujii N and Burger M: CXCR4 chemokine receptor and integrin signaling co-operate in mediating adhesion and chemoresistance in small cell lung cancer (SCLC) cells. Oncogene 24: 4462-4471, 2005. 
11. Taron M, Rosell R, Felip E, Mendez P, Souglakos J, Ronco MS, Queralt C, Majo J, Sanchez JM, Sanchez JJ and Maestre J: BRCA1 mRNA expression levels as an indicator of chemoresistance in lung cancer. Hum Mol Genet 13: 2443-2449, 2004.

12. Ma L, Wen S, Zhan Y, He Y, Liu X and Jiang J: Anticancer effects of the Chinese medicine matrine on murine hepatocellular carcinoma cells. Planta Med 74: 245-251, 2008.

13. Yan Z, Jikai J, Xiaoshan L, et al: Differentiation and apoptosis in K562 erythroleukemia cells induced by matrine. Natural Med 52: 295-299, 1998.

14. Li CQ, Zhu YT, Zhang FX, Fu LC, Li XH, Cheng Y and Li XY: Anti-HBV effect of liposome-encapsulated matrine in vitro and in vivo. World J Gastroenterol 11: 426-428, 2005.

15. Liu J, Zhu M, Shi R and Yang M: Radix Sophorae flavescentis for chronic hepatitis B: A systematic review of randomized trials. Am J Chin Med 31: 337-354, 2003.

16. Zhang JP, Zhang M, Zhou JP, Liu FT, Zhou B, Xie WF and Guo C: Antifibrotic effects of matrine on in vitro and in vivo models of liver fibrosis in rats. Acta Pharmacol Sin 22: 183-186, 2001.

17. Zhang LP, Jiang JK, Tam JW, Zhang Y, Liu XS, Xu XR, Liu BZ and $\mathrm{He}$ YJ: Effects of matrine on proliferation and differentiation in K-562 cells. Leuk Res 25: 793-800, 2001.

18. Zhang YQ, Huang GS, Wang Z, Guo Y and Zhang HY: Effects of matrine on the relative molecules expression of proliferation and apoptosis in K562 cells. Zhongguo Yi Xue Ke Xue Yuan Xue Bao 23: 333-336, 2001 (In Chinese).

19. Wang Y, Peng C, Zhang G, Liu Y, Li H and Shan J: Study on invasion and metastasis related factors in differentiation of SMMC-7721 cells induced by matrine. Zhong Yao Cai 26: 566-569, 2003 (In Chinese).

20. Han Y, Zhang S, Wu J, Yu K, Zhang Y, Yin L and Bi L: Matrine induces apoptosis of human multiple myeloma cells via activation of the mitochondrial pathway. Leuk Lymphoma 51: 1337-1346, 2010.

21. Luo C, Zhu Y, Jiang T, Lu X, Zhang W, Jing Q, Li J, Pang L, Chen K, Qiu F, et al: Matrine induced gastric cancer MKN45 cells apoptosis via increasing pro-apoptotic molecules of Bcl-2 family. Toxicology 229: 245-252, 2007.

22. Zhang L, Wang T, Wen X, Wei Y, Peng X, Li H and Wei L: Effect of matrine on HeLa cell adhesion and migration. Eur J Pharmacol 563: 69-76, 2007.
23. Hou G, Li N, Ma Y-H, Chen X-B, Wang X-F and Luo S-X: Expression of Survivin and P-glycoprotein in non-small cell lung cancer and their relationship with the effectiveness of Matrine and pacilitaxel. Chin J Cancer Prev Treat 20: 350-353, 2013.

24. Liu B, Peng XC, Zheng XL, Wang J and Qin YW: MiR-126 restoration down-regulate VEGF and inhibit the growth of lung cancer cell lines in vitro and in vivo. Lung Cancer 66: 169-175, 2009.

25. Janmaat ML, Kruyt FA, Rodriguez JA and Giaccone G: Response to epidermal growth factor receptor inhibitors in non-small cell lung cancer cells: Limited antiproliferative effects and absence of apoptosis associated with persistent activity of extracellular signal-regulated kinase or Akt kinase pathways. Clin Cancer Res 9: 2316-2326, 2003

26. Danielsen T, Hvidsten M, Stokke T, Solberg K and Rofstad EK: Hypoxia induces p53 accumulation in the S-phase and accumulation of hypophosphorylated retinoblastoma protein in all cell cycle phases of human melanoma cells. Br J Cancer 78: 1547-1558, 1998

27. Takeuchi K, Choi YL, Togashi Y, Soda M, Hatano S, Inamura K, Takada S, Ueno T, Yamashita Y, Satoh Y, et al: KIF5B-ALK, a novel fusion oncokinase identified by an immunohistochemistry-based diagnostic system for ALK-positive lung cancer. Clin Cancer Res 15: 3143-3149, 2009.

28. Wu P, Dugoua JJ, Eyawo O and Mills EJ: Traditional Chinese medicines in the treatment of hepatocellular cancers: A systematic review and meta-analysis. J Exp Clin Cancer Res 28: $112,2009$.

29. Efferth T, Li PC, Konkimalla VS and Kaina B: From traditional Chinese medicine to rational cancer therapy. Trends Mol Med 13: 353-361, 2007.

30. Efferth T, Dunstan H, Sauerbrey A, Miyachi H and Chitambar CR: The anti-malarial artesunate is also active against cancer. Int J Oncol 18: 767-773, 2001.

31. Efferth T, Sauerbrey A, Olbrich A, Gebhart E, Rauch P, Weber HO, Hengstler JG, Halatsch ME, Volm M, Tew KD, et al: Molecular modes of action of artesunate in tumor cell lines. Mol Pharmacol 64: 382-394, 2003.

32. Ooi LS, Wang H, Luk CW and Ooi VE: Anticancer and antiviral activities of Youngia japonica (L.) DC (Asteraceae, Compositae). J Ethnopharmacol 94: 117-122, 2004. 